\title{
How comes we need to think about (which) diversity? What tools do we need to do so?
}

\section{Danielle De Lame}

\section{Q OpenEdition \\ 1 Journals}

\section{Electronic version}

URL: https://journals.openedition.org/eastafrica/400

DOI: $10.4000 /$ eastafrica.400

ISSN: 2790-1076

\section{Publisher}

IFRA - Institut Français de Recherche en Afrique

\section{Printed version}

Date of publication: 1 September 2013

Number of pages: 11-21

ISSN: 2071-7245

\section{Electronic reference}

Danielle De Lame, "How comes we need to think about (which) diversity? What tools do we need to do so?", Les Cahiers d'Afrique de l'Est / The East African Review [Online], 47 | 2013, Online since 07 May 2019, connection on 09 December 2021. URL: http://journals.openedition.org/eastafrica/400 ; DOI: https://doi.org/10.4000/eastafrica.400 


\title{
How comes we need to think about (which) diversity? What tools do we need to do so?
}

\author{
Danielle de Lame
}

\section{Introduction}

$\mathbf{O}_{\text {ver the last century, and until quite recently, human societies have been }}$ though about in terms of corporate entities. In the wake of a switch in dominant ideology, however, societies - and it remains to see how they represent themselves as such - have increasingly stressed their diversities, relegating the perception of entities - and their political organisation as such - in the shadow. While, as social scientists, we can analyse the current discourse on societal diversity and its effects, we cannot do so without also questioning the conditions of its production and its ideological functioning as both a distraction and a tool for mobilization (Althusser 1970). The scale, however, is different. While a discourse in terms of nation-state conceals diverging interests among the citizens, the current discourse on diversity in society transposes a representation of the world as a "global village" onto ideal nations without either borders or classes. Under both paradigms, however, what we are asked to do as citizens of "imagined communities" (Anderson 1996) is to conceive of our links to "the" world and translate this representation into corporate action or acceptation. We are thus brought back to the reassuring perception of solidarity. As social scientists, we are brought to one of the founding fathers of sociology, Emile Durkheim. We shall contextualize his thought historically and contrast it with current conceptions of diversity as social binding tool. Drawing on works by historians and social scientists, we shall then question the representation of a globalized world with some of its realities as a background. We shall try to connect this perception with its correlate that is an increased accent on identities, and suggest analytical tools relevant to a sound methodological use of the term.

Durkheim described human behaviours that, at first sight, would appear as purely individual ones, such as suicide, as enshrined in societies and linked to patterns of social cohesion. This was his major step towards establishing the social character of human behaviour. In his book Suicide, he could correlate selfmurder with social isolation and anomy, a condition of unruliness of society. Social cohesion appears, then, as paramount to the wellbeing of human individuals as much as it is important for societies in themselves to be organized in such ways to make their survival and reproduction possible.

Durkheim, in his first important book The Division of Labour in Society (1893), opposed two forms of solidarity: a mechanical solidarity based on similarities (which he associated with so-called archaic societies), and an organic 
solidarity based on the necessary articulation of complementary diversity in industrial societies conceived according to the reigning paradigm, at the time, that of the nation-state. The image called forth by Durkheim in the notion of organic solidarity is that of the human body and of the nation-state as a body with its flows regulated by borders in an analogy with the body envelope. This concept of state, as Benedict Anderson (1996) demonstrated, is very much about an "imagined community" and is related to the nationalist mobilizations of the 19th century. We should, however, keep the notion of "imagined community" in mind for the sake of understanding experiences of belonging, or references to belonging, that are generally resorted to for the sake of mobilization.

If we talk about mobilization, the questions immediately arise: mobilization by whom and what for? If simple answers can be given under the paradigm of the nation-state, mobilization based on national identity in the context of 19th century's imperialism, for example, by comparison, the construction of an identity based on the perception of economic complementarity is more problematic and subject to ruptures when the exploitative character of this complementarity comes forth, as, for example during the 1848 revolution in France, or during the "Paris Commune" in 1870. The repression of such violently expressed discontents is then based on the mobilization of those who strongly identify with the state and its superior reasons. The two types of solidarity are, then, at play in processes linked to particular circumstances or, maybe even more, to dominant representations of the circumstances.

As stated in introduction to this conference, "societies define themselves as a set of pluralities that are acceptable in various degrees according to time and place." While taking the "geo-historic evolution of social diversity" as its core, this conference rests on definitions of society and the ways societies build and define themselves. Hence, it is methodologically important to contextualize Durkheim's conceptual attempt. We shall see that it also remains interesting to think along this first sociological theorisation. Durkheim's terminology and theory are imbedded in the spirit of his time, a time of intense discovery and conquest by the West to which he belonged. In this context, the nation-state appeared as a paramount and unquestionable marker and referential "We, the conquerors") facing a welcoming, or unwelcoming, perceived chaos engulfed in the qualifier "archaic societies" supposed to be organized under the paradigm of similarity, as their diversity and mode of organization were ignored. Arguably, this was not, at the time, foreign to the attempt at making the market more penetrable trough a standardization of rules that colonizers imposed as far as their interests commanded. Confronted with "the Other", colonists saw the weird group as uniform, partly imbued with their prejudices, partly deluded by a uniformity the menaced group may have been opposing to the invader. The view of the Other as uniform was in tune with the circumstances of conquest, as confrontation fosters mobilization based on common interests on both sides and puts similarities forward while fading away organic interactions that usually care for everyday survival. The so-called civilizing mission aimed at a marginal 
incorporation into the dominating world, with a contribution in raw material and agricultural produce. A re-organization of the world was needed. "The Other" needed to be named and re-organized in order to make colonial contacts possible (Todorov 1982). A vocabulary common to both colonizer and colonized needed to be produced. Ethnologists were sent to the field. While they produced knowledge that was useful to administrators and traders, they privileged a vision of societies closed onto themselves, and drew borders rather than they identified flows, stressing and often accentuating a socio-cultural uniformity that fostered stereotypes. The way people identified themselves could be quite different from the identity conveyed by ethnological studies. Some economic groups such as the Djula of West Africa were perceived as "tribes" while they comprise merchants of different origins who converted to Islam for the sake of trade. Tourism and art, in the case of the Dogon, for example (Ciarcia 2003) or the religious enterprise in need of standardized translations of the Bible (in the case of the Mongo of current DRC) resulted in the creation of new ethnic identities (Chrétien \& Prunier 1989; Hobsbawm \& Ranger 1983). Examples are many. Quite understandably, the perception of empires, with their complexities and nuanced administration, were puzzling the colonizers. In such case, local structures were very often used under the label "Indirect Rule" under British colonization and with some accommodation of the practice in French colonies. But let us go back to tribal stereotypes and the alleged "mechanic solidarity".

As no group can survive in the total absence of "organic" ties (be it the vary basic exchange of women underlined by structuralist anthropology and which results in the building of a unit of exchange that defines the world from the standpoint of those practicing it), one cannot but see this approach of societies based on a so-called mechanic solidarity as a pure produce of its time, a projection of the common vision shared by evolutionist ethnographers and conquerors and by the classes commissioning them. History, seen at the time as being based on writing, relegated these societies to the status of "traditional" ones, with the timeless connotation this qualifier entails. After Hobsbawm and Ranger (1982), we know that all societies are historical, and that the references to "tradition" respond to specific kinds of interests, can be imbedded in the creation and mobilization of identities, and that the so-called tradition, if it can be entirely invented is, in any case, constructed. Turning now to the "organic" type of solidarity described by Durkheim, we should also scrutinize the circumstances of the production of the concept. The description Durkeim gives of this type of solidarity rests on a vision of societies as well enclosed entities, indeed, very similar to an ideal notion of a nation-state where again, borders matter more than flows of goods and people, but, in reality, organize the flows for the sake of social reproduction, privileges included. In fact, the end of the 19th century was very much a time of migrations and travel, possibly a time of more diversity than our time is, some historians say. Shying away from the colonialist approach is certainly tempting, but, because we can discern some similarities between current processes of market penetration and these past situations, between the 
imposition of external rules at different periods in time, and between ideological references to the need for belonging and solidarity, albeit on a new scale, it is worth examining both the concept of globalization (and the representations it generates), and the accompanying urgency to deal with diversities.

Intercontinental contacts are very ancient. Accounts of old travel, when they exist, give us some clues as to how diversity was apprehended in the antiquity. Our European-centred perception would point to the Middle East as an area of the most intense contacts, with written accounts going back to the Greek historian Herodotus (4th century BC). However, when we read Ibn Battuta's accounts (14th century), we have to expand the notion far away to include all the Southern Mediterranean coast, the Easter coast of Africa down to present-day Mozambique, Iran, Irak and the Asian coast of the Indian Ocean down to India. Such travel was made possible thanks to the common ground laid by Islam and the Ouma, the community of believers. Trade also created common ground for travel and made it possible, for example, to travel across the Gobi Desert and further to China, as did the Venetian Marco Polo and his uncles (13th century). Well before these documented travels, there are proofs of continuing exchanges linking countries so far away one from the other as Indonesia and Ancient Rome (Dick-Read 2005), and along the American coast of the Pacific Ocean, earlier than 13.000 BC (Pringle 2011). Thinking in terms of contacts, connections, networks of which the actors and their strategies can be identified and analyzed makes it impossible to see colonisation as a kind of protoglobalization: it imposed restrictions on complex trading networks and Africans were "forced into imperial economic systems focused on a single European metropolis" (Cooper 2001: 205). Access to independence fostered internationalization but no kind of globalization.

Globalization is not, then, about global contacts. It does not seem to be related only on the intensity of these contacts either. Returning to more recent times, history shows the peak of migrations to be placed between 1815 and 1913 (with an extreme diversity of populations in cities, in particular). What we see at work are networks and roads, and it does not help us putting the process of a supposed globalization back in time, and there is no reason to do this, as we shall see. The exercise, indeed, suffices to help us scrutinize similar processes today, and to discover that it applies in a similarly unsatisfactory manner to the slave trade, to the colonization and decolonization processes and to the side effects of the structural adjustment programs on the countries it pretends to integrate (however not on equal footing) in the world market. We can then wonder about the new guise market integration has taken, at the same time as the word globalization was becoming popular and fostered an accent on diversity in the general discourse, making identities blossom in representations and discourse both in the general public and in social sciences. In social sciences, after a decline for any analysis based on the primacy of economy, and a shift from studies based on social dynamics and strategies, a trend in the discipline has promoted 
descriptions of "identities" that went hand in hand with an increased perception of diversity and a lowering of formal normativity in everyday life. The "spontaneous" creation of norms and the resulting collective - and partial identity resulting from this, comprehends the right to be "different" (from whom?) while on the other hand, resorting to the law where tolerance used to be the norm, is in the increase. Paradoxes and contradictions abound, and this should lead social scientists to scrutinize their ultimate source and meaning. It is remarkable that growing socio-economic inequalities are being mentioned again, more often than not under the morally unquestionable duty to fight poverty, but rarely analysed. The Marxian paradigm of analysis has been lurking, albeit shyly, from behind the academic circles, while some currents in anthropology, firmly based in the observation of facts, have never stopped to describe the inequalities in accessing what globalization claims to offer.

If we want to make sense of the overwhelming discourse on globalization, with a supposedly increased diversity and/or a menace for diversity, we first need to check if, historically, this paradigm entails more connectivity and of which kind, along which networks, for what sake, across which borders... Economists, sociologists, historians, social anthropologists are all concerned about the study of facts such as these, and about there effects. The current discourse on globalization implies, indeed, that there are no borders at all. On this respect, the general discourse, and the very use of the word "globalization", leaves aside countries and individuals that remain unconnected, and incorporate a large number of peoples and persons only as marginal confirmations of an alleged global integration. Flummoxed by the seemingly limitless capacity for ICT communication, do we not forget to distinguish between the haves and the have nots and the use various categories of people can make of it?

Referring to globalization while, more often than not, resorting to the socalled "global village" created by the Word Wide Web, induces the representation of the world as increasingly uniform, yet universally connected, with travel and flows of goods and people, inducing a rather paradoxically increased diversity. If we now switch to the neo-liberal ideology as the ultimate template for what seems to lay behind the notion of globalization, with its injunctions to open the markets and standardize local rules accordingly we are lead to scrutinize the multi-level creation of norms and the contradictions between affirmations of belonging (aspects of identity) and the need for social cohesion. By the same token, it makes it necessary, first of all, to better define what we call "globalization", then, to assess societal diversity - which diversity? - being one of its consequences. Aside of being a stream-lined representation of partial and unequal links, is "globalization", in any way, an analytical concept, a tool to

\footnotetext{
${ }^{1}$ Checking titles under the keyword "identity" on the database http://societies.africamuseum.be with a chosen ordering by year is a quick way to make up ones own mind about this.
} 
comprehend today's world? To the historian Frederick Cooper (2001), it is not, as his manifold guises let us suspect at once.

The word travels under (at least) three guises. Cooper distinguishes (Ibid: 192-193):

"The Banker's Boast": the opening of the markets will, as far as governments comply with its dictates, promote the well being of all thanks to the famous trickle down effect. Dynamics of implementation are not put under scrutiny as, should they be, they would quit the realm of an idealized globe.

"The Social Democrat's Lament": acceptance of the discourse but militant reaction with a mobilization of the nation-state as a barrier against its evil, "an institutional basis for enforcing social and civic rights".

- The "Dance of Flows and Fragments" accepts the two first aspects but adds a socio-cultural move that we could, as it is quite trendy among anthropologists, drop on the rack of "glocalization", i.e. the transformation of the local by the global. Music, dance, etc, come under this heading, but I find interesting to remark that the economic aspects of this trend are even more seldom analyzed than those of other flows.

While, remarks Cooper, "there is something in each of these conceptions", "what is wrong with them is their totalizing pretensions and their presentist periodization" (Ibid: 193).

While the two first types of globalization discourses evoked just a while earlier still evolve under a paradigm that can make sense of a sort of Durkheimian "organic" integration, the third one forms the background for discourses that, more often than not, oversimplify the perception of social phenomena but, this time in the course of a bottom-up approach that would be engulfed in the "reference reality" (Baudrillard 1994: 6) of "globalization", a representation that masks the fact that there is no "profound reality". Corporate identities are seen as the foundation of society with self-labelling processes caring for a feeling of existence in an atomized society: "new tribes" are partial, temporary, and often linked to consumption patterns. They promote, nevertheless, a potentially mobilizing discourse resorting to "identity". Social anthropologists are being trained to avoid stereotypes and lumped categories and to distinguish actors, strategies, etc. In this perspective, they might well owe some of their tools to historians who are keen on critical approaches of documents (including observation, oral texts, pictures, etc.) and put observation in a temporal perspective making sense of the critically observed present. Together with Cooper, we scrutinized the notion of globalization that is very often linked to the one of diversity in public discourse. We now turn towards a critique of the notion of identity that underlies the one of diversity. 


\section{What does then "identity" bring us when thinking about diversity?}

To coin Brubaker and Cooper, themselves quoting George Orwell in the first paragraph of an important article with title "Beyond Identity": "The worst thing one can do with words is to surrender to them" and he continues: "let the meaning choose the word, and not the other way about" (Orwell, "Politics and the English Language", 169-170). Identity is another word, indeed, that has been used with very little questioning about its analytical capacities. The first distinction that needs to be made is between the use of the term "in the vernacular idiom of contemporary politics" and its use in social sciences the substance of which it affects. "In response to the cascading identitarian claims of the last three decades, public discourse, political arguments and nearly every field of the social sciences and humanities have been transformed..." (Brubaker \& Cooper 2000: 28). While the word has recently become pervasive, in the late 1970's already, scientists have been complaining about its over-use. This did prevent neither the proliferation of the word, nor the belief in the multiplication of jeopardized human specificities. Before putting the accent on diversity under scrutiny, it seems to me necessary to understand the very notion of identity that diversity implies. In order to try and foster a betterment in the conceptualization of, for example, particularistic claims, Brubaker \& Cooper (Ibid: 4-5) suggest to distinguish between categories of practice (categories of everyday life experience) and categories of analysis, with terms like race, nation, citizenship, democracy ... and identity, belonging to both categories.

Which are, according to these authors, the key uses of "identity"?

1. "As a ground for political or social action... it is used to underscore that the action is governed by particularistic self-understanding" (Ibid. 6-7).

2. As a specifically collective phenomenon, "identity" underscores sameness expected to manifest itself in solidarity; literature on social movements resorts to this use of the word (Ibid. 7).

3. "As a core aspect of individual or collective selfhood, or as a fundamental condition of social being, identity is invoked to point to something allegedly deep, basic, abiding, or fundational" (id.);

4. ... "identity is invoked to highlight the processual, interactive development of ... group-ness" that can make collective action possible... (id.)

"Understood as an evanescent product of multiple and competing discourses, the word is invoked to highlight the unstable, multiple, fluctuating and fragmented nature of the contemporary self' (Ibid: 8).

Analysing "identity talk", however, does not presume the existence of identities. Hence the question of the authors: do we need this "deeply ambiguous term"? They think not and suggest some alternative analytical idioms, keeping the word "identity" in only its strong meanings that preserve the common-sense of the word (the one people and groups have, must be discovered and can be mistaken, and, when collective, implies strong notions of group-boundedness and 
homogeneity" (Ibid: 10). When used in its weak, ambiguous, acceptations, a number of other words could be resorted to:

- "Identification" points to a process and is thus void of a reifying connotation; categorization can often be more appropriate (the state can be an agent of categorization); Brubaker \& Cooper point to the input of the social movement literature as it emphasized the interactive...mediated process through which collective solidarities and self-understandings develop"

- Self-understanding: "a sense of who one is" belonging to the Bourdieusian category of "sens pratique"

- Commonality, connectedness, groupness: "emotionally laden sense of belonging to distinctive group involving a sense of solidarity with fellow group members ... and a felt difference or even antipathy towards outsiders" (Ibid: 19).

To these meanings, one could add some more. Identity is also often used in a more Foucaldian perspective, to refer to the process of self-building. It is also used in a more superficial approach, as a synonym for "label" or selflabelling. The inventory is probably endless.

Very much an ideological gimmick derived from a fascination for the Internet (www), the imagery of globalization promotes a perception of identities that differ from the old tribe or ethnic group in that identities are posited as not in isolation, but juxtaposed, and in need of a reconnection that the Internet is supposedly providing. Statistics and empirical data on the use of the web and mass media seldom accompany considerations about the so-called "world culture". The nation-state is mobilized in various ways, including as an intermediary on the trans-national scene and an authority discharging itself of some of its prerogatives on private companies (Hibou 1999; de Lame \& Mazzochetti 2012).

Recent studies on ethnicity have illustrated the historicity of ethnicity as much as its contextual use and processual nature. Ethnic groups used to be as fluid as any other identity, with the fixed character of their notion very much an outcome of cognitive frameworks and administrative enterprise. Similarly, and in tune with Durkheim's theory, groups encompassed as based on the sharing of similar characteristics, and the self-perception of groups as such, seem to call for external coordination and conflict management, with tolerance of diversity being the most obvious instrument. This standpoint, paradoxically, may legitimise more state intervention, more categorization (with the incumbent discrimination) and a distraction from growing economic inequalities resulting, and fostering an organic solidarity based on exploitation" ${ }^{2}$. Linked to "globalization" and "identities", is the notion of "diversity". Menaced by a standardization and

${ }^{2}$ In academic circles and among broader audiences, this consideration runs parallel to the continuing stress on identity and diversity; see, for example W.B. Michaels 2006: "The Trouble with Diversity..." 
categorization imposed from above, but also, in some respects, embraced with enthusiasm by many as a token of modernity (Ferguson 2006) and as a response to the need for reassuring state intervention (Hibou 2011), the diversity of human practices - or its perception - becomes standardized while an emotionally connoted commonality, however often artificial or partial, substitute old links only to an extent. Calling for respect for diversity is very much a matter of defining (and prioritizing) identities, and hence related, at the same time, to the description of social integration and to the elimination of criteria that would not match the formatted ideal.

In my opinion, as anthropologists are well equipped to analyze universals and particularistic properties as well as larger processes, strategies and discourse, they can also demystify the use of terms that are hardly of analytical use. Thinking about diversity is then paramount to the discipline as well as to the fostering of social justice to which the call for diversity is only one (dis)guise.

\section{Conclusion}

The current preoccupation about an allegedly increased diversity that needs, anyway, to be assessed historically, is probably fostered by the perception of a threat on social cohesion and the search for means to keep together significant (and meaningful) human groups in a context where conflicts apparently based on un-reconciled "identities" have been thriving. Interestingly, it coincides with the perception of a threat, this time a real one, on biodiversity, but also with the absence of restrictions on the destruction of ecological niches or vegetal species for the sake of corporate economic gains. Diversity has long been conceived as a condition for complementarity, or even, for solidarity. The first word that springs to mind when talking about social cohesion is thus "solidarity". Let us immediately underline that social cohesion necessarily entails a delimitation of a human group that seems, at first sight, difficult to conceive of under the "reference reality" of a "global society". While, for example, the reference reality of a global society can call for international agreements about a reduction of the emission of CO2 in the context of a global fight against a socalled "global warming" implementing the agreements mobilizes particularistic strategies based on national economic interests.

Just as the representation of the nation has been mobilized in the past, globalization can be seen as calling for mobilization resorting, this time, to another scale of "imagined community" for the sake of accrediting a worldwide economic enterprise. Envisaged as a trans-national set of rules enabling crossborder trade and de-localization, globalization has been accompanied by the world circulation of models (ethical, consumptive, etc.) aiming at a reduction of state expenditures, with the incumbent set of privatisation. Commercial flows freed from political restrictions to trade have transformed the role of states; they have also conveyed the image of a world caught in processes of standardization. 
One could argue that this move, with its accent on flows and its accent on uniform regulations and standardization of property rights has enhanced feelings of disjunction between sets of norms. While fears for a loss of one's own "identity" can fuel reactionary withdrawals, it is usually agreed by anthropologists that changes brought about from the outside world are usually assimilated in manners specific to the context of their reception. It remains that combining a promotion of "modernization" with an accent on reified traditions mobilized when it is useful to do so foster, at the same time, a stiffening of reference identities, and a craving for a "belonging to the world". The international political motto has not only transformed the role of the state, combined with the contradictions within the system of reference as well as with other societal aspect such as individualized consumption patterns, may have combined to lower the perception of solidarities of an organic type (of which the nation-state has been seen as an example) or to transfer it on the virtual WWW that, to those in its multifarious margins, is an icon of modernity. Locally, and in response to suggested channels of belonging to the world, we witness the creation of substitutive norms fostering feelings of belonging based on similarities, and the construction of new "tribes" not so foreign, in their representation, to the stereotypes presiding to descriptions of imagined communities on the eve of colonization.

In the wake of IMF and World Bank paradigms, social sciences adopted terms of vocabulary such as "identity" or "globalization", often without much critical insight. The number of publications with titles comprising the word "identity" increased dramatically, hinting at a need for a feeling of belonging and the making of simplified, often delocalized, "communities" 3 based on an imagined generalisation of very partial, often virtual, links and interests. This change in perception translated into studies on identity and conflict that avoided but also, quite interestingly in studies of new modes of domination in the margins of the so-called state monopoly on legitimate violence, in the wake of Foucault's theory of power. More generally, societal shifts and the world imagined as a reference community, demand an organization of diversities that, locally, are not perceived as complementary and are subject to change. More often than not, conflicts resulting from economic strategies are translated into ethnic - or similar" violence in the wake of the confrontation of identities defining respective rights. While the Durkheimian model for social cohesion needs to be assessed in the historical setting of its production, it is still useful as a critical tool. It remains, then, to the social scientist, to resort to the more rigorous methodology developed by the discipline that Durkheim's work contributed to shape.

\footnotetext{
3 The word "community" can easily be imbued with ideological connotations. It fosters mobilization by referring to a communality of interests which may be restricted to partial aspects activities and erase diverging interest.
} 


\section{Bibliography}

Althusser L. 1970, Idéologie et appareil idéologique d'Etat, Paris: Maspéro.

Anderson B. 1996 [1983], Imagined Communities, London: Verso.

Battuta I. 2004, The Travels of Ibn Battuta: in the Near East, Asia and Africa, 1325 1354 Dover Books on Travel.

Baudrillard A. 1994 [1981], Simulacra and Simulation, Ann Arbor: University of Michigan Press.

Brubaker R. \& Cooper F. 2000, "Beyond Identity", Theory and Society, 29, pp. 1-47.

Chrétien J.-P. \& Prunier G. 2003, Les ethnies ont une histoire, Paris : Karthala

Ciarcia G. 1998, "Ethnologues et 'Dogon'. La fabrication d'un patrimoine ethnographique", Gradhiva, 24, pp. 103-115.

Cooper F. 2001, "What is the Concept of Globalization Good for? An African Historian Perspective", African Affairs, C, 300, pp. 189-213.

de Lame D. \& Mazzocchetti J. (dir), 2012, Interfaces empiriques de la mondialisation. African Junctions under the Neoliberal Development Paradigm, Tervuren: Musée royal de l'Afrique centrale.

Dick-Read R. 2005, The Fantom Voyagers. Evidence of Indonesian Settlement in Africa in Ancient Times, Winchester: Thurston Publication.

Durkheim E. 1893, De la division du travail social, Paris : Presses universitaires de France. English translation 1997, The Division of Labour in Society, New York: The Free Press.

-1897, Le Suicide. Etude de sociologie, Paris: Presses universitaires de France. English translation 1951, Suicide: a study in sociology, New York: The Free Press.

Ferguson J. 2006, Global Shadows. Africa in the Neoliberal World Order, Durham/London: Duke University Press.

Hibou B. (dir), 1999, La privatisation des Etats, Paris: Karthala.

—2011, Anatomie politique de la domination, Paris: La Découverte.

Hobsbawm E. \& Ranger T. (eds), 1983, The Invention of Tradition, Cambridge: Cambridge University Press.

Michaels W.B. 2006, The Trouble with Diversity: How we Learned to love Identity and Ignore Inequality, New York: Metropolitan.

Pringle H. 2001, "The First Americans", Scientific American, 305, 5, pp.36-41.

Todorov T. 1982, La conquête de l'Amérique : la question de l'autre, Paris: Seuil. 